\author{
Людмила Волинець \\ кандидат економічних наук, доцент, \\ дочент кафедри транспортного права та логістики \\ Національного транспортного університету, \\ м. Київ, Україна, е-mail: Volinec_3@ukr.net, \\ https://orcid.org/0000-0002-5064-2349 \\ Наталія Васільцова \\ старший викладач кафедри економіки \\ Національного транспортного університету, \\ м. Київ, Украӥна, е-mail:pilipenko_natali@ukr.net \\ https://orcid.org/0000-0002-9897-5310
}

\title{
ОСОБЛИВОСТІ ДОСВІДУ ЗАКОРДОННИХ КРАЇН, ЩОДО ФОРМУВАННЯ ТАРИФУ НА ПЕРЕВЕЗЕННЯ ПАСАЖИРІВ АВТОТРАНСПОРТНИМИ ПІДПРИЕМСТВАМИ
}

Анотація. Визначено необхідність вдосконалення формування тарифу перевезення пасажирів автотранспортними підприємствами.

Обгрунтовано роль та місце транспортних послуг, вплив рівня задоволення потреб населення у якості пасажирських перевезень.

Проаналізовано закордонний досвід формування тарифів на пасажирські перевезення, а також розглянутий інструментарій та засоби державного регулювання цін і тарифів в Україні.

Доведено, що автотранспортні підприємства, які здійснюють міські пасажирські перевезення потребують перегляду формування тарифів на послуги 3 пасажирських перевезень у зв'язку з постійним ростом фактичних витрат, які не залежать від господарської діяльності підприємств-перевізників. У зв'язку зі збільшенням мінімальної заробітної плати, значним подорожчанням запчастин, стрімким ростом трудової міграції водіїв, автоперевізники міста не мають можливості підвищити заробітну плату, підтримувати рухомий склад у належному технічному та санітарному стані, виконувати зобов'язання згідно 3 чинними договорами на перевезення пасажирів на міських автобусних маршрутах загального користування.

Запропонований досвід закордонних країн, щодо специфіки формування тарифу на перевезення пасажирів автомобільним транспортом, застосування якого дозволить вдосконалити існуючі методичні підходи формування тарифу на послуги з перевезення пасажирів на міських автобусних маршрутах загального користування, а також врахувати інтереси громадян, органів місцевого самоврядування та суб'єктів підприємницької діяльності, які надають послуги 3 
перевезення пасажирів автомобільним транспортом. А це, в свою чергу, стимулює автомобільних перевізників до якості та безпеки перевезень, сприяє розвитку добросовісної конкуренції, поліпшенню рівня послуг, що надаються. Крім цього, задовольнятиме підприємницький інтерес, сприяти вирішенню завдань по підвищенню можливостей усіх суб'єктів підприємницької діяльності в забезпечення потреб споживачів у послугах, залученню інвестицій у його розвиток на досягнення сталих економічних умов роботи.

Ключові слова: тариф, якість транспортних послуг, підприємстваперевізники, рухомий склад, собівартість перевезення, економічна ефективність.

\section{Volynets Lyumyla}

candidate of Sciences (Economics),

Associate Professor, National Transport University, Associate Professor, Department of Transport Law and Logistics,

Kyiv, Ukraine, e-mail: Volinec_3@ukr.net

https://orcid.org/0000-0002-5064-2349

Vasiltsova Natalia
National Transport University,
assistant lecturer, department of Economics,
Kyiv, Ukraine, e-mail: pilipenko_natali@ukr.net
https://orcid.org/0000-0002-9897-5310

https://orcid.org/0000-0002-9897-5310

\section{PECULIARITIES EXPERIENCE OF FOREIGN COUNTRIES REGARDING THE FORMATION OF TARIFF FOR PASSENGER TRANSPORTATION BY MOTOR VEHICLE ENTERPRISES}

Abstract. The necessity of improvement of formation of the tariff of transportation of passengers by the motor transport enterprises is defined.

The role and place of transport services, the influence of the level of satisfaction of the needs of the population on the quality of passenger transport are substantiated.

The foreign experience in the formation of fares for passenger transportations is analyzed, and also the tools and means of the state regulation of the prices and tariffs in Ukraine are taken into consideration.

It has been proven that road transport enterprises engaged in urban passenger transport need to review the formation of fares for passenger transport services in connection with the constant growth of actual costs, which do not depend on the economic activity of transport enterprises. Due to the increase in the minimum wage, a significant rising in prices for spare parts, the rapid growth of labor migration of drivers, the city's carriers do not have the opportunity to increase wages, maintain rolling stock in proper technical and sanitary condition, fulfill obligations under existing contracts for passenger transportation on the public city bus routes.

The experience of foreign countries on the specifics of the formation of the fares for passenger transport by road, the application of which will improve the existing methodological approaches to the formation of tariffs for passenger services on public 
bus routes, as well as take into account the interests of citizens, local governments and businesses activities that provide services for the carriage of passengers by road. And this, in turn, stimulates road carriers to the quality and safety of the transportation, promotes the development of fair competition, improving the level of services provided. In addition, it will satisfy the business interest, help solve problems to increase the capacity of all business entities to meet the needs of consumers in services, attract investment in its development to achieve sustainable economic conditions.

Keywords: fares, quality of transport services, enterprises-carriers, rolling stock, cost of transportation, economic efficiency.

Formulation of the problem. Every year, citizens demand quality public transport, which would solve many pressing problems of Ukrainian cities - due to constant traffic jams that paralyze the city, high levels of air pollution, economic and psychological losses of city residents. Fast and convenient public transport would also make a good impression on tourists from other countries. But there is a problem with the financing of passenger transport. The underfunding of the industry and, consequently, the low quality of the provided transport services are monitored.

Today, urban passenger transport companies need to review the formation of current tariffs for passenger transport services in connection with the constant growth of actual costs, which do not depend on the economic activity of transport companies.

Due to the constant increase in costs, there is a risk of disruption of the schedule on bus routes, as well as the implementation of the necessary amounts for current and major repairs of vehicles, reconstruction and modernization of fixed assets. Currently, there are two unclaimed bus routes among the economic entities that provide passenger transportation services due to unprofitability. This situation has a certain sphere of negative impact, which extends to both business entities that provide passenger transportation services and the population of the city. The negative situation extends to the authorities (local governments) in terms of receiving complaints from the public about non-compliance with bus schedules, which worsens the city's transport services, as well as slowing down the development of business in the field of road transport.

Analysis of recent research and publications. Problems of the formation of tariffs for passenger transportation by road are complex and multifaceted.

A negative consequence of the tariff inconsistency with the level of economically justified costs is the further physical depreciation of fixed assets of motor companies, which can lead to increased accidents and reduced quality of passenger transport services.

At different times, the following domestic and foreign specialists were engaged in solving aspects of this issue: Bazilyuk AV, Bogomolova NI, Vorkut AI, Vorkut TA, Gurnak VM, Boyd Colin W., Ortuzar J. de D, Winston C. AV, Levkovets PR, Yanovska VP and other

The purpose of the article - to substantiate the feasibility of introducing a new method of forming tariffs for passenger transportation, taking into account the experience of foreign countries.

Presenting main material. State tariff policy is an important tool for regulating the economic and social processes of the state. It is necessary to ensure a balance of 
economic interests of the state, transport companies and consumers of services. According to Regulation (EU) 1370/2007, which should enter into force on 1 November 2022, which provides for the provision of passengers with reliable, safe and efficient service through regulated fair competition, transparency and quality of services. It is transparency and clarity in financial calculations between all market participants that will give impetus to the development of the industry.

In Ukraine, the tariff policy is formed based on the "Methodology for calculating tariffs for passenger road transport services" approved by Order №1175 of 17.11.2009., from which the planned net income from other activities is deducted [1]. The result is divided by the annual volume of passengers carried, ie

$$
T_{M}=\frac{\left(S_{\Pi}+\Pi_{\Pi}\right)-Д_{i}}{Q_{\Pi}},{ }^{2 p н} / \mathrm{nac}
$$

where: $T_{M}$ - tariffs for passenger transportation services on public city bus routes, which are carried out in the normal mode of movement; $S_{\Pi} \quad$ - planned annual cost of services, UAH; $\Pi_{\Pi}$ - planned annual income from the provision of services, UAH;

$Q_{\Pi}$ - planned annual volume of passenger traffic, pass .; substantiated by the Carrier on the basis of actual indicators work or is established by the results of the survey passenger flows;

$Д_{i}$ - planned annual net income from other activities related to the provision of services.

Calculations are made according to normative indicators, which do not always accurately reflect the actual transportation costs, overestimating or underestimating them. The number of transported passengers, privileged and non-privileged categories is also unreliable.

The main feature of public transport is its general accessibility for the lowest-paid categories of the population. The principle of universal accessibility of public transport is achieved by methods of state regulation of tariff policy. Tariffs and fares must ensure the socially necessary level of mobility of the population, regardless of their place of residence and distance from the "center". The difference between the estimated required and the actually established level of payment is that the state must compensate a particular carrier according to the actual volume of traffic.

The experience of forming tariffs in other countries is interesting. Thus, in Singapore, the cost of travel by bus is calculated depending on the distance traveled.

The current tariff model was introduced in July 2010. Tariffs are reviewed annually. There are two fares in buses: contactless cards and cash. Some groups of passengers are issued discounted cards, which entitle them to discounted fares at a discount. There are two types of fares based on distance: basic fares and express fares, which apply to most bus routes in Singapore [1].

Under bus contracts, all fare is collected by the government, including the Land Transport Authority (LTA), which then regularly pays bus operators a fixed amount of money to reimburse their operating costs. The Public Transport Council (PTC) is the body under the Ministry of Transport that regulates fares on public transport. The 
Board conducts annual surveys to revise tariffs to adjust them, and new tariffs usually take effect in late December. The current tariff adjustment formula is as follows and applies from 2018 to 2022 :

Fare $2020=0,5 \mathrm{cCPI}+0,4 \mathrm{WI}+0,1 \mathrm{EI}-0,1 \%+\mathrm{NCF}=4,4 \%$

The tariff adjustment formula is based on five components:

1. Basic Consumer Price Index (cCPI);

2. Wage Index (WI): change in average monthly earnings (average annual national income) compared to the previous year, adjusted for any changes in the employer's contribution rate to the CPF; $2.6 \%$ in 2020 ;

3. Energy index (EI): change in the energy index, which consists of changes in the cost of electricity and diesel fuel; $-9.4 \%$ in 2020.

4. $0.1 \%$ - the coefficient of productivity withdrawal is set for the period from 2018 to 2022 .

5. Network Bandwidth Ratio (NCF): change in NCF compared to the previous year, $3.9 \%$ in 2019 .

However, due to COVID-19 and the economic downturn, the Public Transport Council (PTC) has decided not to provide a tariff adjustment quota of $4.4 \%$ for the 2020 tariff revision to help public transport and mitigate the impact of COVID-19. Instead, the full amount of the tariff adjustment was carried over to the next tariff revision measure in 2021.

In Poland, the share of public transport is almost $60 \%$, with urban transport accounting for the bulk of passenger traffic. The main mode of urban transport in Poland is buses, the number of which is about 11.5 thousand, which are provided mainly by municipal operators. At the same time, there are private transport companies, whose market share varies from a few to several tens of percent, which operate on certain lines in agreement with local authorities. In Warsaw, the entire public transport network is served by one company - the Warsaw Public Transport Administration (ZTM or Zarząd Transportu Miejskiego). Due to this, there is a single ticket in Warsaw, which can be used throughout the city. In Warsaw, tariffs in urban public transport are determined depending on the distance traveled [2]. Accordingly, there are two tariff calculation systems:

- the fixed system in which the tariff does not depend on the distance;

- mixed (differential) system, in which the change of the tariff occurs depending on the marked transport zones, within which the movement of passengers takes place. This system is the main one when determining the level of the tariff.

The state policy of formation of tariffs in each state has the specificity, but the final result is general - a high level of quality of transportations of passengers and economic efficiency of work of the enterprises-carriers.

Conclusions. The use of foreign experience in the formation of tariffs for passenger transportation, will improve the transportation process on public city bus routes, carried out in the normal mode of operation, at an economically reasonable level, will promote the stable operation of business entities providing passenger 
services, timely payment wages, payment of taxes to the budget, ensure the regularity of buses on the route, improve the quality of passenger services.

\section{Лimepamypa:}

1. Волинець Л.М. Концептуальні засади сталого розвитку транспортної галузі україни в контексті фінансової безпеки держави. Управлінський аспект забезпечення фінансової безпеки Украӥни: монографія / За ред. Черевка О.В., Черкаси, 2018. С. 252-272.

2. Гурнак В.М., Гурнак М.В., Волинець Л.М.. Обгрунтування необхідності зміни приоритетів інвестування розвитку інфраструктури різних видів транспорту в сучасних умовах. Управління проектами, системний аналіз та логістика. №9. 2017. С. 33-39.

3. Базилюк А.В., Назаренко Я. Я Тарифоутворення у сфері пасажирських перевезень: Монографія. Київ: Національний транспортний університет, 2010. 197 с.2. Гурнак В.М., Гурнак М.В., Волинець Л.М.. Обгрунтування необхідності зміни приоритетів інвестування розвитку інфраструктури різних видів транспорту в сучасних умовах. Управління проектами, системний аналіз та логістика. №9. 2017. С. 33-39.

4. Міністерство інфраструктури України [Електронний ресурс]. - Режим доступу: https://mtu.gov.ua

5. Кучерук Г.Ю. Якість транспортних послуг: управління, розвиток та ефективність: Монографія. Київ: ДЕТУТ, 2011. 205 с.

\section{References:}

1. Volynets L.M. (ed.) (2018) Kontseptualni zasady staloho rozvytku transportnoi haluzi ukrainy v konteksti finansovoi bezpeky derzhavy [Conceptual principles of sustainable development of the transport sector of Ukraine in the context of financial security of the state]. Upravlinskyi aspekt zabezpechennia finansovoi bezpeky Ukrainy [Management aspect of financial security of Ukraine]. Cherkasy, pp. 252-272[in Ukrainian].

2. Gurnak V.M. \& Volynets L.M. \& Gurnak M.V. (2017). Obhruntuvannia neobkhidnosti zminy pryorytetiv investuvannia rozvytku infrastruktury riznykh vydiv transportu $\mathrm{v}$ suchasnykh umovakh [Justifying the need to change priorities of investing in the development of infrastructure of different types of transport in modern conditions] Upravlinnia proektamy, systemnyi analiz i lohistyka - Project management, systems analysis and logistics, 9, 33-39 [in Ukrainian].

3. Bazyliuk A.V.\& Nazarenko I.I. (2010). Taryfoutvorennja u sferi pasazhyrsjkykh perevezenj [Tariff-setting in the field of passenger transport]. Monograph. Kyiv: NTU [in Ukrainian].

4. Ministerstvo infrastruktury Ukrainy [Ministry of Infrastructure of Ukraine]. Retrieved from https://mtu.gov.ua [in Ukrainian]

5. Kucheruk Gh.Ju. (2011). Jakistj transportnykh poslugh: upravlinnja, rozvytok ta efektyvnistj [Quality of transport services: management, development and efficiency]. Monograph. Kyiv: DETUT [in Ukrainian]. 